\title{
7 \\ Becoming 'Overstayers': The Coloniality of Citizenship and the Resilience of Pacific Farm Workers
}

\author{
Makiko Nishitani and Helen Lee
}

The Australian Government once described Pacific people as too 'unsophisticated' and 'unsuited' to settle in Australia and as a likely source of social problems. ${ }^{1}$ Ironically, this statement was made in a Cabinet submission in 1971, when the government was making progress towards abolishing the 'White Australia' policy in an attempt to signify Australia's departure from racist immigration policies. This contradiction vividly illustrates Australia's ambivalent attitude towards migrants from the Pacific. More than four decades later, the Australian Government's view of Pacific people as permanent migrants has scarcely changed, although, in recent years, it has introduced the Seasonal Worker Programme (SWP), which encourages temporary labour migration from Pacific countries. This chapter explores the complex ways Australia's immigration regime has influenced Pacific people's mobility through forms of inclusion and exclusion, and their equally complex responses. In particular, we focus on the irregular migrants often referred to as 'overstayers' both by Australian authorities and within Pacific migrant communities.

$1 \quad$ Hamer, “"Unsophisticated and Unsuited”, 104. 
Pacific people's worldview tends to emphasise a borderless world shaped by connections with kin and kin-like relationships. ${ }^{2}$ Nevertheless, national borders and immigration laws inevitably shape people's opportunities for migration in various ways, determining whether migration is permanent or temporary, as well as assigning different rights and benefits according to their immigration status. Most of the Pacific people in Australia who are 'overstayers' have entered the country legally using a visitor visa, but then remained after the expiration of their visa, making their immigration status 'unlawful'.

Pacific overstayers have been present in Australia for many years and the dominant narrative about them has long been one of 'illegal immigrants' stealing jobs and costing taxpayers, as reflected in this newspaper report from 1989:

[Name], 39, an illegal immigrant from Fiji, used his real name to take a job and then four aliases to milk the welfare system of $\$ 84,000$ in dole payments. The Victorian judge who later jailed [Name] condemned the case as an outrageous rip-off of Australian taxpayers ... A Tongan immigrant and his wife, who entered Australia illegally, cost the Australian Legal Aid office \$1 million in their successful appeal against deportation orders ... Illegal immigrants are costing taxpayers more than $\$ 400$ million a year. Because the illegals are on the run from the moment they arrive here, they are much more likely than legitimate citizens to engage in systematic fraud of welfare, financial and tax systems. ${ }^{3}$

To challenge that narrative, we apply the lens of the 'coloniality of power', ${ }^{4}$ arguing that the category of 'overstayers' is socially and politically produced by Australia's immigration system. Drawing on field work conducted since 2014, we also focus on Pacific overstayers' voices, which reveal their concerted efforts to legalise their status and their resilience despite the precariousness of their everyday lives in Australia. ${ }^{5}$ Our research participants are mainly

2 Hau 'ofa, 'Our Sea of Islands'; Ka' ili, Marking Indigeneity.

3 Bob Bottom, 'Illegal Migrants: How They Cost Us \$400M', The Sydney Morning Herald, 28 August $1989,1$.

4 Quijano, 'Coloniality of Power'.

5 This research has been funded by an Australian Research Council Linkage Project grant and a La Trobe University Research Focus Area (Transforming Human Societies) grant. Our partner organisations are the Sunraysia Mallee Ethnic Communities Council (its EO Dean Wickham is our partner investigator) and the Mallee Sports Assembly. Participants include over 100 Pacific people, including Tongans, Cook Islanders, Fijians, Solomon Islanders and Ni-Vanuatu, who completed questionnaires and in-depth interviews and participated in focus group discussions. In addition, interviews were conducted with key stakeholders such as farmers and service providers in the area. 
farm workers who live in north-west Victoria in the towns of Mildura and Robinvale. ${ }^{6}$ Although many are, or were, overstayers, they have made a significant but often unacknowledged contribution to the economy of the region, known as Sunraysia, for many years. ${ }^{7}$

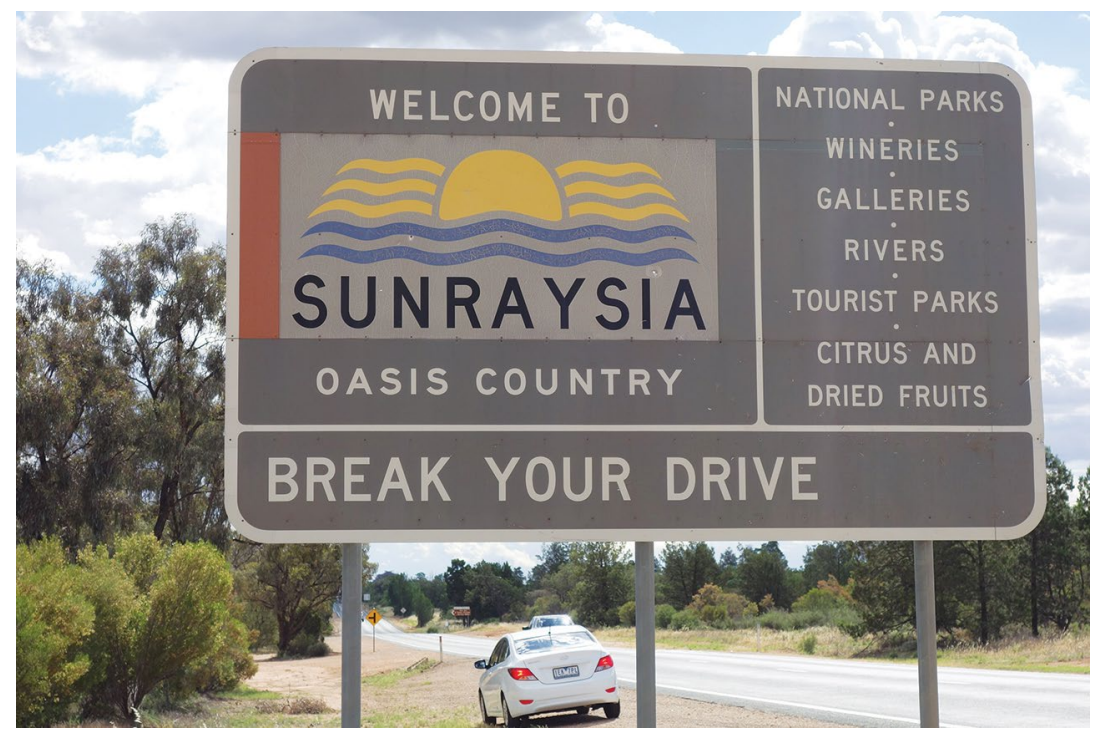

Figure 7.1: 'Welcome to Sunraysia', north-west Victoria.

Signs like these present an idealised view that obscures the work done by Pacific Islanders and others to sustain the local horticultural industry. Still, for some informal workers, Sunraysia is an 'oasis' of sorts, offering relative protection from surveillance and migration regimes.

Source: Photograph by Makiko Nishitani.

According to the 2016 census, Mildura has a population of 32,738, including various Pacific groups, whereas Robinvale has a population of only 3,088 and its Pacific population is predominantly Tongan. ${ }^{8}$ Sunraysia is a highly productive horticultural region and Pacific farm workers are employed in citrus orchards and in the many vineyards, which

$6 \quad$ Nishitani and Lee, 'Invisible Islanders?'

7 We believe naming the towns will not have negative implications for our research participants. The presence of overstayers and other 'illegal' migrants is shared knowledge in the towns as well as among stakeholders, and it was openly discussed by many witnesses, including our partner investigator, Dean Wickham, at the parliamentary public hearing, 'Inquiry into Establishing a Modern Slavery Act', in October 2017. The Hansard is publicly available.

82016 Census Quickstats: Mildura', Australian Bureau of Statistics, released 23 October 2017, accessed 14 March 2019, www.censusdata.abs.gov.au/census_services/getproduct/census/2016/quick stat/SSC21671?opendocument; '2016 Census Quickstats: Robinvale', Australian Bureau of Statistics, released 23 October 2017, accessed 14 March 2019, www.censusdata.abs.gov.au/census_services/get product/census/2016/quickstat/SSC22171?opendocument. 
produce table grapes and wine, surrounding the towns. In addition, due to growing demand within Australia, almond farms are expanding in the Robinvale area, where some of the Tongan settlers are employed to operate machinery for harvesting and processing. Although the emergence of corporate farming, or 'agribusiness', is rapidly changing the horticultural landscape and associated industries, relatively small farming 'blocks' are still predominant. Many Italian and Greek migrants, who moved into the area in the nineteenth century and during the two world wars, established these blocks. They arrived in search of opportunities that were unavailable in the cities under the 'White Australia' policy. These early migrants:

Experienced constraints on employment and economic opportunities, being restricted to poorly paid, low status, low skilled jobs, often with poor working conditions, in the service sector and as 'factory fodder' in the cities. Fruit picking and seasonal work in intensive horticultural areas such as the Goulburn Valley and Sunraysia often gave an introduction to the district and also some horticultural skills such as picking and pruning. Purchasing smallscale farms presented opportunities for economic advancement for immigrants and others with limited opportunities for social mobility in other sectors of the economy. ${ }^{9}$

These Southern European farmers have now become the main employers of the many Pacific people who have moved to the region since the 1980s. Tongans were the first to arrive in the area, also in search of job opportunities. Many were already overstayers and had been living in Melbourne or Sydney but had been unable to find work due to their immigration status. They were attracted by the relative lack of surveillance in regional communities and ready availability of farm work. Other Tongans initially went to the area on visitor visas and decided to overstay for various reasons: primarily, the ease of finding work without being questioned about their immigration status. Over time, some were caught by immigration officers and deported, or had their visa applications rejected and left Australia, but others were able to get permanent residency or Australian citizenship and many continue to live in the area today. It was not unusual for it to take more than 10 years and several migration review tribunals for overstayers to 'win' permanent residency status, while others gained it through amnesties. ${ }^{10}$ There were three amnesty periods in Australia in the 1970s and 1980, which aimed to 'regularise the status

9 Missingham, Dibden and Cocklin, 'A Multicultural Countryside', 136.

10 As of July 2015, the Migration Review Tribunal is called the Administrative Appeals Tribunal. 
of people who had overstayed their visas'. ${ }^{11}$ After the last amnesty in 1980, special legislation was enacted that was 'designed to block government from declaring amnesties in the future', ${ }^{12}$ and was supported by the main political parties. ${ }^{13}$

Since the last amnesty, 'the Department tightened border controls, instructing officers to be more stringent and look more closely at the bona fides of people applying for visitor visas..$^{14}$ Meanwhile, Tongans and other Pacific migrants, including Cook Islanders, Solomon Islanders and Fijians, have continued to move into regional Victoria. Cook Islanders are eligible for New Zealand passports by birth and are thus entitled to work rights and unlimited residence in Australia, although New Zealand citizens rights to welfare benefits have been restricted since 2001. Other Pacific people have arrived in the region with a range of immigration statuses and their communities now include irregular migrants (much like other regional areas, as discussed by Mackay and Guinness, this volume). Many of our research participants shared the view that issues associated with immigration status are among the most serious problems facing these communities. As scholarship on national borders shows, immigration status and citizenship are not only legal concepts but also historically and socially constructed. ${ }^{15}$ Thus, each immigration status should not be treated as a 'transparent and self-evident fact'. ${ }^{16}$ Instead, it is necessary to consider the role of changing immigration policies and their allocation of rights.

\section{Australia's Immigration Policies and the Coloniality of Citizenship}

Within the boundaries of nation-states, citizenship has levelling effects that ideally provide equal rights to the members of those states. However, on a global level, each nation-state's citizenship provides different opportunities. In this sense, citizenship is a crucial 'opportunity-allocating

11 Mence, Gangell and Tebb, A History of the Department of Immigration, 58.

12 David Solomon, 'Australia's "Last” Amnesty for Illegal Aliens Gets Mixed Results', The Christian Science Monitor, 7 January 1981, www.csmonitor.com/1981/0107/010758.html.

13 Bob Bottom, 'Illegal Migrants: How They Cost Us \$400M', The Sydney Morning Herald, 28 August 1989.

14 Mence, Gangell, and Tebb, A History of the Department of Immigration, 58.

15 De Genova, 'Migrant "Illegality" and Deportability in Everyday Life'; Gonzales and Sigona, 'Mapping the Soft Borders of Citizenship'.

16 De Genova, 'Migrant “Illegality” and Deportability in Everyday Life', 432. 
institution of the modern era. ${ }^{17}$ Although citizenship can be acquired when the requisite conditions are met, for most people, citizenship is ascribed at birth. As Boatcă and Roth argue, this 'birthright transmission of citizenship' and resultant unequal 'allocation of life chances' is 'the very proof of its coloniality'. ${ }^{18}$ They claim that 'the institution of citizenship has developed in the West through the legal (and physical) exclusion of non-European, non-White and non-Western populations from civic, political, social and cultural rights.'. ${ }^{19}$

Tracing Australia's immigration policies, Claudia Tazreiter states that 'Australia has developed a proactive approach to immigration-actively recruiting and selecting prospective newcomers', while excluding the negatively defined 'Other' since white settlement. ${ }^{20}$ This exclusion of nonEuropeans was enforced in two ways. Aboriginal people were excluded 'by the denial of citizenship' and acts of violence and segregation, and non-European migrants were barred entry through legislation, most significantly the Immigration Restriction Act 1901 that aimed to 'preserve the social and political fabric of a settler society'. ${ }^{21}$ Sanjugta Vas Dev argues that:

Within this historical trajectory of White settlement and its emphasis on control of 'the other', constructions of asylum-seeker identity as 'illegal', 'burdensome' and 'threatening' have been thus viewed as a continued form of racism traced back to British colonisation, in an attempt to unite the predominantly white community first against indigenous people and then against all non-Anglo outsiders. ${ }^{22}$

Immigration and citizenship laws are intricately related to projects of state building. ${ }^{23}$ As mentioned at the start of this chapter, the Australian Government once described Pacific Islanders as 'unsuited' to settle in the country and regarded them as a potential source of problems. Australia's strong preference for skilled migration continues to prevent many Pacific Islanders from permanently migrating to the country and they have been admitted only on particular terms, such as through the SWP. However, Pacific people have continued to resist the restrictions and conditions

17 Shachar, 'The Birthright Lottery: Response to Interlocutors', 1.

18 Boatcă and Roth, 'Unequal and Gendered', 205.

19 Boatcă and Roth, 'Unequal and Gendered', 191.

20 Tazreiter, Asylum Seekers and the State, 126.

21 Tazreiter, Asylum Seekers and the State, 126-27.

22 Vas Dev, 'Accounting for State Approaches', 38.

23 Kipnis, 'Anthropology and the Theorisation of Citizenship', 265. 
that attempt to control their mobility and have sought alternative ways to be able to live and work in Australia, often taking the risk of becoming overstayers to achieve their goals.

Using quantitative data on patterns of inequality in more than 96 countries, Korzeniewicz and Moran demonstrated that international migration is the 'single most immediate and effective means of global social mobility for populations in most countries of the world'. ${ }^{24}$ This motivates many people to be 'able and willing to risk illegal, undocumented or non-citizen status in a rich state'. ${ }^{25}$ Pacific overstayers exemplify this pattern; however, they have always been a minority in relation to the overall number of people similarly attempting to improve their life chances by overstaying their visas in Australia. For example, in 2012, there were 1,090 Tongan passport holders with visitor visas who had not returned to Tonga before their visa expiry date. By contrast, 7,800 overstayers held Chinese passports. ${ }^{26}$ If non-return rate is used as the measurement, Tongans' rate of 5.6 per cent was the highest of all countries, whereas the Chinese non-return rate was only 0.32 per cent. Focusing on rates rather than numbers has enabled the Australian Government to justify instituting, since the 1990s, 'strict requirements for visitors from Fiji, Tonga and other Pacific countries because of people overstaying in the past'. ${ }^{27}$ This has included family members living in Australia often being required to pay security bonds, usually between AU\$5,000 and AU\$15,000 per person if they want to sponsor relatives from their home country via the Visitor Visa - Sponsored Family stream..$^{28}$

\section{A 'Closed' Path to Citizenship and Permanent Migration}

Australia's strong preference for skilled migration, particularly in relation to permanent migration, limits the options for Pacific people who want to live in Australia but do not have access as New Zealand citizens through Australia's travel agreement with New Zealand (see Faleolo,

\footnotetext{
24 Korzeniewicz and Moran, Unveiling Inequality, 107.

25 Boatcă and Roth, 'Unequal and Gendered', 199.

26 'Population Flows: Immigration Aspects (2010-11 ed.)', Department of Immigration and Citizenship, accessed 16 December 2013, www.immi.gov.au/media/publications/statistics/popflows 2010-11/pop-flows.pdf (site discontinued).

27 Maclellan and Mares, 'Remittances and Labour Mobility in the Pacific', 46.

28 'Fact Sheet -Sponsored Family Stream', Department of Home Affairs, accessed 20 April 2018, archive.homeaffairs.gov.au/about/corporate/information/fact-sheets/54sponsored.
} 
this volume). Having a passport from one of the Pacific nations places people in a disadvantaged position when seeking to live and work in Australia and the almost closed path to permanent residency is one of the factors that produces overstayers. One of the limited options available to people is to apply for a protection visa, which is common for Fijians due to the political situation in their country, although the success rate is low. Another option is family reunification visas, including carer visas or partner visas. However, carer visas are capped each year and are difficult to obtain. For example, in Mildura, one Tongan couple with four children had been caring for aged parents (Australian citizens) for more than four years without themselves having legal immigration status. They had originally intended to stay in Australia for a holiday, but when the aged parents became unwell they felt they could not leave them. Although they were intending to apply for the carer visa, they could not afford the high application fees. As of October 2017, onshore applications for carer visas cost AU\$1,625 and a child visa cost AU\$2,415 per applicant.

Compared to carer visas, partner visas do not have any caps and are usually granted if a couple can show evidence of a genuine relationship. As one Tongan female overstayer observed, 'the luckiest people are those who are married to a [Australian] citizen'. It is not unusual for Australianborn Pacific women to find partners from among those without work permits; sometimes they fall in love but in other cases family members of overstayers ask second-generation women's family members to agree to the marriage. Since 2011, the application fee for partner visas has dramatically increased. Whereas in 2007 it cost AU\$2,060, as of July 2017, the fee was $\mathrm{AU} \$ 7,000,{ }^{29}$ which is extremely difficult for farm workers to save, leading many to remain without legal rights to live in Australia even if they are eligible for this visa. In addition, while the United States and New Zealand have avenues for Pacific people without specified skills to obtain permanent residency through their lotteries (the Pacific Access Category Resident Visa in New Zealand and the Diversity Visa Lottery in the United States), Australia does not have a similar system.

29 'Charges - July 2007', Department of Home Affairs, accessed 9 April 2018, www.homeaffairs. gov.au/FormsAndDocuments/Documents/990i/990i0707.pdf (site discontinued); 'Partner Visa (subclasses 820 and 801)', Department of Home Affairs, accessed 9 April 2018, www.homeaffairs. gov.au/trav/visa-1/801- (site discontinued). 


\section{The Seasonal Worker Programme and the Emergence of 'Absconders'}

As MacDermott and Opeskin have observed: 'Over a sustained period, the Australian government resisted pressure to give preferential treatment to Pacific Islanders through a temporary work scheme. ${ }^{30}$ Potential problems with such a scheme were debated, most prominently that:

A key concern with temporary labor programs is that workers will overstay their visas and fail to return home when seasonal work ends. Australian immigration officials warn that without 'very strong enforcement', the non-return of seasonal workers would incur significant expenses for government. ${ }^{31}$

However, the government was under pressure from both Australian farmers, who were desperately short of labour, ${ }^{32}$ and the governments of Pacific countries, which were eager to see Australia increase labour opportunities for their people, even if these were only temporary. Eventually, the Pacific Seasonal Worker Pilot Scheme was trialled in 2008-12, then, in July 2012, the SWP commenced.

Although it serves Australia's need for 'unskilled' farm labourers, the SWP has been promoted as a form of development aid, enabling temporary migrants to send remittances to their families in the islands. ${ }^{33}$ An analysis by Andrew Kipnis of the relationship between aid and immigration in the Australian context is relevant here:

Why does the Australian government ... supply aid to some of the same countries from which it severely limits immigration? ... The lens of citizenship provides a harsh answer to this query. The provision of foreign aid outside Australia and the production of illegality within Australia can be seen as linked carrot-andstick strategies to prevent immigration ... From the perspective of a would-be immigrant, the objectives of 'foreign' 'aid' could be seen as intended to identify those 'foreigners' who should be prevented from immigrating and 'aid' them by offering just enough help to induce them not to immigrate. ${ }^{34}$

30 MacDermott and Opeskin, 'Regulating Pacific Seasonal Labour in Australia', 286.

31 Mares and Maclellan, 'Pacific Seasonal Workers for Australian Horticulture', 279.

32 Mares and Maclellan, 'Pacific Seasonal Workers for Australian Horticulture', 273.

33 Mares and Maclellan, 'Pacific Seasonal Workers for Australian Horticulture', 280.

34 Kipnis, 'Anthropology and the Theorisation of Citizenship', 266-67. 
One can observe the coloniality of power in the relationships between Australia and Pacific countries in the SWP, which has parallels with the nineteenth-century 'blackbirding' of Pacific labourers. ${ }^{35}$ The scheme provides no means for workers to permanently migrate to Australia and imposes tighter regulations on them than it does on the non-Pacific workers eligible for other temporary labour schemes. As with other visa categories, Australia has the power to limit eligibility, the number of people admitted from each country and to control how the scheme operates. In addition, Pacific countries are keen to increase the number of seasonal workers they can send, so they are careful to select 'ideal' workers. For example, the Fijian and Samoan governments include fitness tests in the process of recruitment. In its explanation of the implementation of the fitness test, the Samoan Government stated: if Samoa is to increase the number of people participating it is essential they send the best possible people who are physically and mentally fit'. ${ }^{36}$ Similarly, Minister for Employment, Productivity and Industrial Relations Jone Usamate stated that the Fijian Government is recruiting more people from rural areas because 'people living in rural settings were loyal to their employers whilst in New Zealand or Australia. ${ }^{37}$ The SWP accepts men and women aged over 21 who fit the eligibility criteria, although, between 2012 and 2015, the majority of participants were males between 21 and 45 years old. ${ }^{38}$

With the SWP now in place, the Australian Government's concerns about the scheme leading to overstaying have intensified, with a notable shift in language from 'overstayers' to 'absconders'. Whereas New Zealand 'emphasizes the lack of overstaying' in regard to the 'success' of the Recognised Seasonal Employer (RSE) scheme, ${ }^{39}$ the Australian Government is clearly worried that this is not the case for the SWP. The Labour Mobility Assistance Program (LMAP), established by the government to assist countries participating in the SWP, put out a call for research in 2016 and identified a study into Tongan 'absconding' as

35 Connell, 'From Blackbirds to Guestworkers'; Maclellan and Mares, 'Remittances and Labour Mobility in the Pacific'. See also, Stead, this volume.

36 'Fitness Test for Samoan RSE Workers Introduced', Radio New Zealand, 1 May 2017, www. radionz.co.nz/international/pacific-news/329797/fitness-test-for-samoan-rse-workers-introduced.

37 Arieta Vakasukawaqa, 'Nineteen Fijian Seasonal Workers Still on Run in Australia', Fiji Sun, 7 October 2017, fijisun.com.ff/2017/10/07/nineteen-fijian-seasonal-workers-still-on-run-in-aust/.

38 Joint Standing Committee on Migration, Seasonal Change.

39 Rockell, 'Pacific Island Labour Programmes in New Zealand', 246. 
the first priority. This call for research also listed other areas of research priority, including 'issues contributing to SWP workers absconding while in Australia ... and approaches to reducing the number of absconders' ${ }^{40}$

The LMAP call for research noted that 'various unofficial reports on the drivers for absconding' have identified 'poor working conditions' as one factor. ${ }^{41}$ These poor conditions, including the exploitation and ill-treatment of SWP employees, have now been well documented and have received considerable media and scholarly attention. ${ }^{42}$ There is some recognition by the Australian Government of these problems, as indicated by the inclusion of testimony on the SWP within the inquiry into establishing a Modern Slavery Act in Australia, conducted in 2017 by the Joint Standing Committee of the Department for Foreign Affairs, Defence and Trade. Yet, the government's focus remains mainly on the illegal status of those who breach their contracts. SWP contracts tie workers to specific farms, so if they leave those farms and do not return immediately to their homeland, they not only breach the terms of their employment but also risk overstaying their visas. This shift in government discourse is telling, as the label 'absconders' indicates intentional illegality, denotes an abandonment of contracted responsibilities and assumes that the workers will become overstayers. This resonates with the broader shift in political discourse around border control and criminalisation of irregular migrants, as evident in the Australian Border Force Act 2015 and raids on farms in recent years, including in Sunraysia, by Border Force officers.

Given the unequal relationship between Australia and Pacific countries mentioned earlier, incidents of absconding from the SWP give the Australian Government bargaining power with Pacific nations. For example, after confirming that 19 Fijians from the 2015 intake of the SWP were 'still on the run' in 2017, Usamate commented that:

40 Labour Mobility Assistance Program, Call for Expressions of Interest, Research Panel Providing Socio-Economic Research Design and Implementation related to the Seasonal Worker Programme, July 2016, 9 (in author's possession).

41 Labour Mobility Assistance Program, Call for Expressions of Interest, Research Panel Providing Socio-Economic Research Design and Implementation related to the Seasonal Worker Programme, July 2016, 10 (in author's possession).

42 Forsyth, Victorian Inquiry; Segrave, Exploited and Illegal; Nick Toscano, 'Fruit Pickers Paid Pittance, Forced to Work for Weeks', The Age, 25 August 2016, 23, www.smh.com.au/business/work place/fruit-pickers-paid-a-pittance-forced-to-work-five-weeks-straight-20160824-gqzrz3.html. 
Employers from Australia and New Zealand have started to lose interest on recruiting Fijians because they ended up breaching their work contracts. 'The recruitment from Australia and New Zealand employers under the programme is now stagnant, it neither increased nor decreased'. ${ }^{43}$

Fears of losing access to the SWP leads island governments to blame the workers, rather than raising concerns about the conditions they face in Australia. ${ }^{44}$

\section{Pacific Settlers' Views of 'Absconders'}

Within Pacific populations in Australia there are ambivalent views towards SWP workers who leave the scheme and attempt to overstay. A study in Tonga by Lupe Moala-Tupou found that families feared workers would leave the scheme in Australia, abandon their children and stop sending money. ${ }^{45}$ Rather than the Australian Government's term 'absconder', Tongans use the term hola (literally 'run away'). While Moala-Tupou's research found that those who hola were mainly considered negatively by Tongans in Tonga, our research found that settled Tongans in Mildura and Robinvale judge them according to context. For example, when a Tongan man left a group of seasonal workers as soon as they arrived at Sydney airport, this was seen negatively, and Tongan women who were exchanging this news talked about how 'stupid' he was, expressing concern about Tonga's reputation in the SWP. However, the exploitation of seasonal workers is well-known in settled communities and those who hola because of poor working conditions receive sympathy; their decisions to leave the program are considered valid. Fijian participants had similar views, and were also sympathetic to SWP workers who left their workplace due to poor conditions. The strong association between the SWP and exploitation is reinforced by the experiences of these workers who breach their contracts. A second-generation Tongan woman whose family had offered refuge to two 'absconders' described visa and immigration issues as among the largest problems for the Tongan community in Mildura.

43 Arieta Vakasukawaqa, 'Nineteen Fijian Seasonal Workers Still on Run in Australia', Fiji Sun, 7 October 2017, fijisun.com.fj/2017/10/07/nineteen-fijian-seasonal-workers-still-on-run-in-aust/.

44 Hermant, 'Seasonal Farm Workers'.

45 Moala-Tupou, 'The Social Impacts of Seasonal Migration'. 
She explained: 'There is a lot of overstayers here, [it] is because [of these] stupid programs that contractors bringing people from Tonga ... they [contractors] cheat them, then they [workers] take off.'

Overstayers can be paid directly by farmers and have more freedom of movement; consequently, most of our research participants argued that overstaying is preferable to participating in the SWP. Indeed, those who were overstayers expressed sympathy towards SWP workers, whom they regarded as poorly paid, tied to one workplace and often exploited by the contractors. An interview with a Tongan 'absconder' revealed strong pressure from his family in Tonga, which made it impossible to return empty handed. As he was only paid AU $\$ 150$ a week in the SWP, he decided to leave the program and overstay in Australia so he could remit more money. He acknowledged that being an overstayer presents serious problems and was keen to find a way to change his immigration status to stay legally in Australia. However, as with other overstayers, 'absconders' are able to continue to find work as many farmers are more concerned with getting their crops harvested and other farm work done than with identifying which workers are legal. Indeed, a service provider in Mildura reported that farmers do not like to have immigration raids before the harvest season because there will be a significant lack of available labour if overstayers are caught and detained.

\section{The Predicaments of Everyday Life and the Agency of Pacific People}

Pacific people continue to stay and work illegally in regional communities in Australia, using their agency to seek a better life both for themselves and for their families at home by becoming breadwinners. Some of them work within the period of their visitor visas and go home with their savings, but others overstay their visas and send remittances over a long period. As with the majority of other Pacific people in the region, overstayers in Sunraysia typically do seasonal work on farms. Although the stereotype of Pacific horticultural workers is that they are uneducated and unskilled, people's previous occupations are actually diverse. Many were professionals or office workers in their home country, and some had no experience of working on a farm before moving to the area. It is difficult for Pacific people with permanent residence or Australian citizenship to find employment other than farm work due to their stigmatisation as 'fruit pickers'. Those who 
are overstayers have even less choice in their occupation, as they are unable to use their prior skills and qualifications; therefore, they remain in farm work where their visa status is rarely questioned.

Susan, a 57-year-old Fijian woman, had been overstaying in Robinvale for three years at the time of her interview. She was a civil servant in Fiji but, when she retired at age 55, she decided to come to Australia to work. ${ }^{46} \mathrm{Her}$ husband was in the army before his retirement, her son is a school teacher and her daughter is a research officer in a government department in Fiji. Although she and her family members are well educated, she perceived her life in Fiji as hard, especially because she still had to pay her mortgage despite being retired. Working in Australia, she explained, she now earned AU\$600-700 a week and sent AU\$400 of that to family in Fiji towards the mortgage. She referred to paying the mortgage as her 'project', saying that once she achieved her goal she intended to go home. Susan explained what it was like working on a farm on her first day:

When I first started working, like I find it very hard ... First day ... it was very hot because that day it was 42 degrees. Then we were running out of water when we worked there and the place where we work was very far from our cabin. We couldn't walk back to get water ... I just make a few boxes then I sit. I couldn't work anymore because I find it very hard because sitting in the office and come and work in the farm is very different. Yeah, two different things, but then I tried to cope. Next day I take a lot of water and I tried to work more harder. Now I find that it's getting easier.

Moving from being a clerical officer in Fiji to a farm worker in Australia increased her income:

Here it's better. For me I earned $\$ 140$ net a week [back home], but then I had to pay for my house $\$ 100$ a week so I'm just left with $\$ 40$. I know that life is very hard back at home ... Not enough money because cost of living is very high and as I said, what we earn is very less. Even if you just get your money, pay for the bills, buy for the food, buy the petrol for the car so, it's not enough.

46 Most of the Fijian research participants aged in their 50 s and 60 s refer to the change in retirement age in 2006 from 60 to 55 as their reason for migration. 


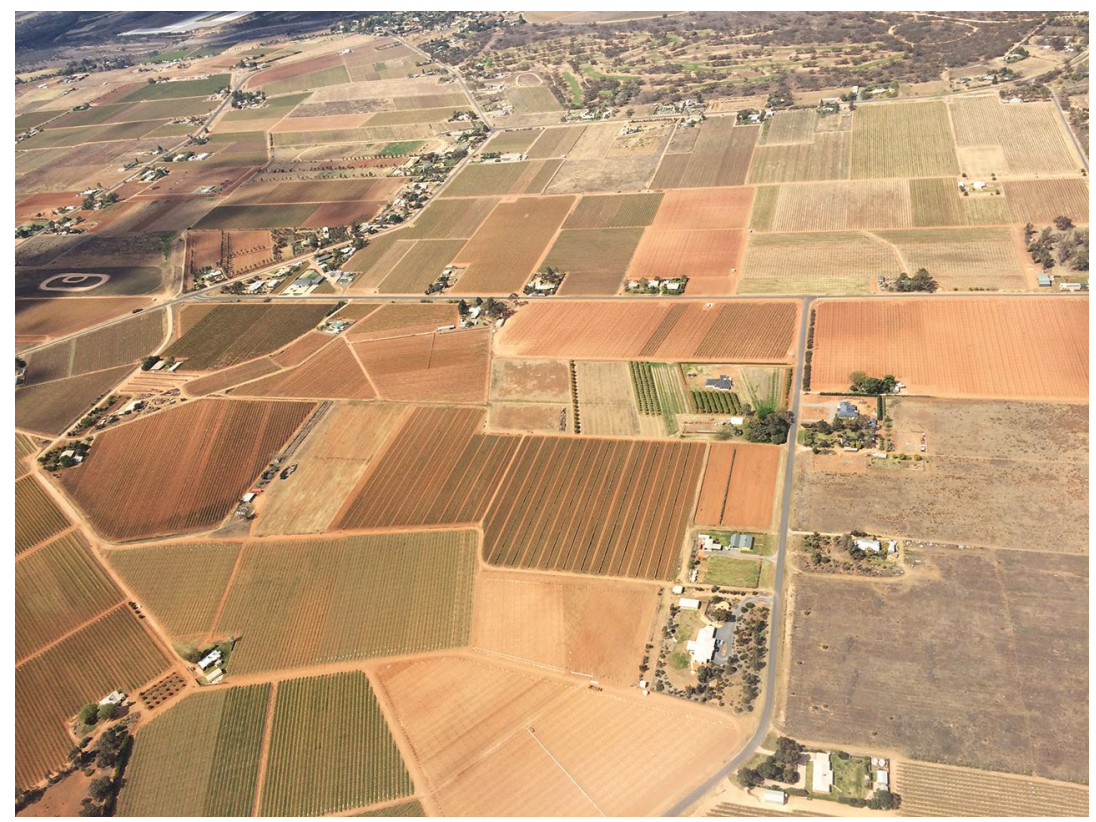

Figure 7.2: An aerial shot of the region, showing the 'blocks' where Pacific Islander migrants work.

Source: Photograph by Helen Lee.

While Susan has a clear goal of paying her mortgage, other people come to Australia to support their family at home. Una, a 72-year-old Fijian woman who entered Australia with a visitor visa in 2000, came here to work because her husband was negligent in supporting her family. She explained:

I was thinking ... who's going to care for my kids, who's going to feed us? Because the way he's drinking too much and sometimes come home and you know, husband like that, so I was planning to come ... I'm the breadwinner of my family, yeah. My own family, my two daughters and my son, and my brother's son, whatever they need I will always support them ... My grandchildren, they're going to school ... so I help them for their school fees and whatever they need. I am the only one in the family [that has an income source].

She proudly reported that she had paid for the renovation of the house in Fiji. Una said her daughter 'always calls me [to say] "mum, this part of the house is finished", and I did that'. She continued: 
Now they said they wanted to repainting the house and I said 'oh, just, because I'll send the money for your food and just take me slowly'... I did it myself. Even my brother they need the help and who helps? It's only me. The Fijian ways of living is like that but I can't leave them, I have to be there for them. Without me; so hard. One of my eldest daughter's daughter she went to New Zealand for two weeks for education or something and they need fare to go.

Overstayers such as Susan and Una become breadwinners but they face financial instability due to the seasonal nature of their work. Such work does not provide security to anyone, and even Australian citizenship holders also struggle financially. ${ }^{47}$ However, those with citizenship and permanent residency can get Medicare and are eligible to apply for welfare payments (with certain restrictions for New Zealand citizens). Overstayers cannot get any benefits, and thus many experience more severe financial insecurity, especially during winter when there are fewer jobs. A Fijian man with a wife and three children, all of whom are overstayers, explained his annual income:

Three months [in summer], I can earn a thousand dollars [a week]. That's only go for three months. After that we slow down ... We do a bit by bit. $\$ 400$ a week, $\$ 500$ a week.

Mele is a Tongan woman in her 40s who was an overstayer for 12 years until she received her permanent residency in 2008. When asked what kind of difficulties she experienced while overstaying Mele said:

The money. Because we had to pay for every single thing that we get. Not like these days, that the government can help us when we have the paper [permanent residency] ... Before, we got nothing from no-one. We only depend on what we are doing in the block [i.e. on the farm]. When it's rain, there's no money ... I was looking forward to go back to school and get something more easier [once her visa was sorted]. Not only easier, but something that you can get the bread and the milk on the table from January to December, because here, it's seasonal work. There is nothing in this country that is seasonal except the work. You can't say to the government, 'Okay, now the grape is finished, I can't pay my house'. No, you still have to pay it. Not only that, but you can't

47 Nishitani and Lee, 'Invisible Islanders'. 
tell your kids, 'Okay we're going to fast this week because there's no job'. No. You have to get something that you can work all the way through to feed your family.

Interviewees who were overstayers described the many difficulties of everyday life. For example, Besi, a Tongan woman who was a former teacher, was overstaying as was her husband and their children:

We don't have Medicare for our medical stuff. We have to pay the full fee of like visiting the doctors. This one [her child] was born here, we have to pay for my blood tests. It's free for the citizen, but us we have to pay 600 plus for one blood test. I find it very difficult because we pay a lot. All the medical things, especially the medical stuff, but the other stuff, it's okay and the school fees too. There's a fee paid by the government for the citizens, but us we have to pay the whole fee. Education fee, trip fees and other fees from curriculum fees.

While some of the irregular migrants live with family members who have citizenship or permanent residency, others live in a farmhouse or a cabin on a farm. Such accommodation typically costs them around $\$ 40$ a week and their living conditions are usually very poor. A Fijian woman on a visitor visa claimed: 'if the Ministry of Health goes to the farmers and checked the farm, I think all the farmhouses are closed. It's no hygiene; there is no hygiene'. Another Fijian woman who lives on a farm complained that she has been worried for three years the roof of the house in which she lives is going to collapse. She and the other Fijians with whom she shares the home have repeatedly asked the owner to fix it without success.

Despite their difficult living conditions, research participants often tried to be positive about their circumstances. When asked for a more detailed description of her poor living conditions, a Fijian female overstayer in her 30s replied instead:

Yeah, maybe, but I'm just, sometimes I'm going to look at it my way, that we don't have working visa, [we are] living here illegally, and the farmers have really, really helped us. Providing us with accommodations. Like if we don't work, if there's no work in the farm, we stay there and don't pay nothing. They don't charge us for rent when there's no work, so we get free rent, free electricity, everything, free gas provided by the farmers. 
Some people also described positive aspects of their work, particularly the camaraderie with fellow Pacific workers. However, overstayers are inevitably in an unequal relationship with their employers, even more than other employees. A Fijian female tourist visa holder, who planned to stay in Australia for only three months while working illegally, observed of overstayers:

The problem is you cannot complain, because you don't have the paper. You're not a resident. I think that's why farmers are still not happy with people with papers [because] they can complain. They can report the matters. Because the farmers, whatever they say that's it. You have to follow. Otherwise, go find other place. You don't wanna lose job, you want to work. See? Even though the box is $\$ 2$, you cannot say anything, just work. ${ }^{48}$ Otherwise, you ask for a raise [and] you're fired.

In addition to financial exploitation, the treatment of overstayers can be far more dangerous and problematic:

Sometimes we never have our lunch, even when it's very hot they keep pushing us to do this, do that ... You know when you stay there they [contractor] know that we are illegal in here, that's why ... Sometimes when it's hot, when it's sometimes 40, 35, 39 degrees and it's hot, and you want to go home and they say just keep going on picking ... Don't let us go home ... We are keeping doing the work because we picking, it's very hard to do that in the hot. (Fijian overstayer, female aged in her 60s)

Although they are aware of their illegal status and are prepared to endure exploitative relationships and harsh conditions, Pacific people also know they are contributing to the economy:

We helping the farmer. Because Australians, they don't want to work. They're very grateful with us Fijians and even Asians ... They want to get the work done. They don't want to get lost of a million things, what they've been planting and growing ... We help them, the farmers ... When you're good to people, your manager or the working place, they see you're a good worker. (Fijian overstayer, female aged in her late 50s)

48 The piece rate for picking table grapes ranges from AU\$2 to AU\$3.50 per box, weighing around 8-10 kg, with rates depending on the quality and kind of grapes and their destination (e.g. exported overseas or sold by domestic supermarkets). 
Pacific overstayers also contribute to their local communities, particularly through the churches. Some of them take leadership roles at church or contribute to choir groups. Others contribute to local sports teams as players, or participate in multicultural festivals as performers. As Gonzales and Sigona observe:

On a daily basis, one's immigration status may be less or more salient to most of their activities. They may be regular in one sense and irregular in another; they may be fully excluded from the legal-political system but able to carry out a range of social interactions and activities. Migrants who have little or no formal rights interact every day with a multitude of state agencies, community institutions, and individuals. These conditions make it possible for both citizens and migrants to sometime operate 'as if the boundaries did not exist'. ${ }^{4}$

\section{The Shifting Status of Overstayers}

For overstayers, national boundaries are hard to forget, as is the fear of possible deportation and the probability that their lives will suddenly and irrevocably change if they are caught. A Fijian female overstayer in her 60s explained:

When I see the police now [I'm] scared because I knew I'm illegal. When the others say that the immigration is in town, nobody will come to town, we just stay in the bush, and just let the people in town buy the food and bring it back to us.

Susan, the ex-civil servant from Fiji, had just received a bridging visa, having applied for a protection visa a week before her interview. She explained why she applied:

Because as we stay like this it's sometimes the immigration come, they [are] trying to get all illegal stayers in the country and every time people have to run away to the bush and hide. That's why I've decided to do something at least to protect me while I'm staying here ... I was just thinking that we can't be running away all the time like that.

49 Gonzales and Sigona, 'Mapping the Soft Borders of Citizenship', 6. 
Before she applied for the visa she was worried:

Because you're not sure, anything can happen at any time ... Interaction is not easy at first ... People might ask you why you come to Australia or what visa you are on ... so I didn't [socialise] ... If you get into an accident then you go to the hospital, then the hospital ask for Medicare and [you get] medical bills ... Every day you just live in uncertainty. You just think if something happen how you going to handle it? ... Sometimes you don't walk freely, you scared to talk to other people and sometimes at night don't really have a comfortable sleep. You're worried and you thinking a lot. Night and day you think a lot ... Always stay frightened all the time and, like, when we hear rumours that they [immigration officers] are around, we don't feel like going anywhere. Just stay lock in your room. It's not safe. Maybe we are like prisoners in our room.

However, this has changed since she submitted her application. She said: 'I feel better now. I'm not really worried like before.' Acquiring a bridging visa is merely a temporary remedy because there is no guarantee that Susan will get the protection visa she applied for, and even then it could be temporary or permanent. Immigration decision-making often seems arbitrary to applicants, and while some successfully get a visa and remain in Australia lawfully, others are rejected. Some of these may try to stay as long as possible by going through an Administrative Appeals Tribunal; among those whose appeals are rejected, some may be apprehended by immigration officers and deported but others will try to stay in Australia.

For overstayers, the pathways to permanent residence are confusing and require English skills, knowledge of the complex immigration system and understanding of categories such as 'refugee'. Una, the 72-year-old woman discussed previously, extended her visitor visa for six months on the advice of her relatives in Australia and then applied for a refugee visa. Her application was rejected and she explained: 'Well they said I am not a refugee then, because I was applying for that and they said no.' When asked why she had applied for a refugee visa, she replied:

Because I just ... [I was] with my friend who fill the form, my friend too we do the same thing. We thought that it might accept us but after all they said 'no Fiji is ... not a refugee country'. 
While some irregular migrants rely on the advice of friends and relatives, others become victims of scams by unregistered 'immigration agents' who take their money, or pay expensive lawyers without achieving a successful outcome.

The term 'overstayers' masks the fact that many people do make contact with immigration officials and try to correct their immigration status. Many irregular migrants make concerted efforts over a long period to be legal, despite the confusing processes and repeated rejections of their applications. Over time, some people successfully acquire permanent residency, but others shift between the categories of illegal and legal, often without fully understanding the reasons for their current status. This is illustrated in the experience of a Fijian woman in her 30s who came to Australia in 2009. Before her visitor visa expired, she applied for a protection visa and immediately was offered a bridging visa with work rights; she received a tax file number within two weeks. Although this bureaucratic process made her status legal, her application was rejected and subsequently rejected again when it went through the Migration Review Tribunal in October 2010, making her 'illegal'. In 2013, immigration officers visited Robinvale to encourage people to reapply for their visas. Together with other irregular migrants, she went to see them and received another bridging visa. She reported: 'We were made legal.' However, the immigration officer told her the only option she had left was to apply for a ministerial intervention. She wrote a letter and then undertook interviews that involved several trips to Melbourne but eventually was rejected again, returning her status to illegal.

Gonzales and Sigona write: 'illegality is a legally and routinely produced status [and] there is a need for a critical examination of the social and political conditions under which people are constructed as "illegal". ${ }^{50}$ The situation for overstayers in Australia is thus similar to 'unauthorized immigrants' in the United States, who:

are viewed as criminals who break the law, precisely because the law does not provide sufficient mechanisms for those who need and want to live and work in the United States to do so legally. ${ }^{51}$

50 Gonzales and Sigona, 'Mapping the Soft Borders of Citizenship', 6-7.

51 Dreby, Everyday Illegal, xii. 
Limited and expensive visa options and confusing processes for seeking legal residence, combined with factors such as economic pressures in the home country and familial obligations, create a situation in which people become overstayers while still desperately attempting to find ways to regularise their status. In this sense, Australia can be seen as 'producing' illegal workers.

\section{Discussion}

Despite the long processes of decolonisation-led independence of previously colonised countries, including many Pacific Islands, ${ }^{52}$ 'durable', 'stable' and long-lasting elements of colonialism remain, and the 'coloniality of power' still shapes global inequality and affects people's everyday lives. ${ }^{53}$ Viewed through the lens of the coloniality of citizenship, the term 'overstayers' appears far from neutral; instead, it masks the unequal opportunities allocated among people within that category. The meaning of 'overstaying' for working holiday makers from wealthy nations like Britain or Japan needs to be understood differently than for Pacific Islanders overstaying entry on a visitor visa or through the SWP. Pacific people's decision to overstay is a demonstration of their agency as they attempt to make their families lives better in the context of ongoing inequalities between their homelands and Australia. Their 'illegal' status is 'produced' because the logic of Australia's immigration regime generally excludes them from permanent migration, only allocating limited 'opportunities' to temporarily provide their labour as seasonal workers. Yet, for some Pacific people, the temporary work offered through the SWP holds a greater risk of exploitation than becoming overstayers, and provides less freedom of movement. They choose to be 'illegal' in the hope of converting that status over time.

Overstaying can entail a range of problems including poor living conditions, precarious employment and fear of deportation, yet almost all research participants who had overstayed their visas claimed to have made a good decision to remain in Australia. For them, the ability to work and support their family in the islands is of paramount importance. They can earn far more money working on a farm in Australia than by remaining

52 Banivanua Mar, Decolonisation and the Pacific.

53 Quijano, 'Coloniality of Power', 533. 
in their Pacific homeland and they are prepared to endure risks, as well as physically challenging labour and often poor working conditions, to do so.

Longer-term options for labour mobility are now being considered for some Pacific nations, but it is unlikely Australia will move away from highly regulated and restrictive schemes that centre on labour migration as a form of development aid. The Pacific Labour Scheme introduced in July 2018, initially for people from Kiribati, Nauru, Samoa, Solomon Islands, Tuvalu and Vanuatu, involves 'low and semi-skilled work opportunities in rural and regional Australia for up to three years'. ${ }^{54}$ The new scheme will not permit workers to bring their families, causing even longer family disruptions than the SWP. Given the government's focus on the problem of 'absconders' from the SWP, it will not be surprising if this scheme has even tighter regulations and controls over the freedoms of the workers involved.

Pacific people continue to be perceived as potential overstayers or 'absconders' from the regulated system who need to be controlled and policed, despite the historically small numbers of Pacific overstayers relative to the overall number of overseas visitors and other temporary immigrants who have remained in Australia beyond their visa's expiry date. The governments of Pacific countries appear to be more concerned with ensuring ongoing access to labour migration opportunities than with the conditions in which their people are working in Australia. In a sense, they are contributing to the ongoing coloniality of power by surrendering to Australia's governance of Pacific people's labour.

Yet, some Pacific people continue to resist that coloniality by seeking ways to live and work in Australia despite immigration restrictions. People's lived experiences of moving between legal and illegal statuses demonstrate how (il)legality is a product of the bureaucratic system, not a static definition. Nevertheless, the implications of being labelled 'illegal' —or, in the case of the SWP, as 'absconders' - are significant. The labels stigmatise and dehumanise overstayers, for whom daily life is marked by insecurity both in the seasonal work undertaken and in the constant threat of being caught and deported. As a result, people remain vulnerable to exploitative employers and labour contractors, and to immigration scams and expensive

54 'Australia's Pacific Engagement', Department of Foreign Affairs and Trade, accessed 27 April 2018, dfat.gov.au/geo/pacific/engagement/Pages/stepping-up-australias-pacific-engagement.aspx. 
lawyers. Our research participants have varied reasons for overstaying that typically centre on family responsibilities, including a desire to care for elderly parents, obligations to support their families in the islands, or women's need to support themselves and their children. They, like other Pacific people in rural Australia, have amply demonstrated their resilient agency both through their engagement in arduous horticultural work and in their tenacious attempts to regularise their immigration status.

\section{Bibliography}

Banivanua Mar, Tracey. Decolonisation and the Pacific: Indigenous Globalisation and the Ends of Empire. Cambridge: Cambridge University Press, 2016.

Boatcă, Manuela and Julia Roth. 'Unequal and Gendered: Notes on the Coloniality of Citizenship'. Current Sociology Monograph 64, no. 2 (2016): 191-212. doi.org/10.1177/0011392115614781.

Connell, John. 'From Blackbirds to Guestworkers in the South Pacific. Plus Ça Change...?'. The Economic and Labour Relations Review 20, no. 2 (2010): 111-22. doi.org/10.1177/103530461002000208.

De Genova, Nicholas. 'Migrant "Illegality" and Deportability in Everyday Life'. Annual Review of Anthropology 31 (2002): 319-37. doi.org/10.1146/annurev. anthro.31.040402.085432.

Dreby, Joanna. Everyday Illegal: When Policies Undermine Immigrant Families. Oakland: University of California Press, 2015.

Forsyth, Anthony. Victorian Inquiry into the Labour Hire Industry and Insecure Work Final Report. Melbourne: Department of Economic Development, Jobs, Transport \& Resources, 2016.

Gonzales, Roberto and Nando Sigona. 'Mapping the Soft Borders of Citizenship: An Introduction'. In Within and Beyond Citizenship: Borders, Membership and Belonging, edited by Roberto Gonzales and Nando Sigona, 1-16. Abingdon: Routledge, 2017. doi.org/10.4324/9781315268910.

Hamer, Paul. "Unsophisticated and Unsuited": Australian Barriers to Pacific Islander Immigration from New Zealand'. Political Science 66, no. 2 (2014): 93-118. doi.org/10.1177/0032318714554495.

Hau'ofa, Epeli. 'Our Sea of Islands'. The Contemporary Pacific 6, no. 1 (2004): $147-61$. 
Hermant, Norman. 'Seasonal Farm Workers Receiving Less than $\$ 10$ a Week after Deductions, Investigation Reveals'. ABC News, 26 February 2016, www. abc.net.au/news/2016-02-25/seasonal-farm-workers-receiving-as-little-as\$9-a-week/7196844.

Joint Standing Committee on Migration. Seasonal Change: Inquiry into the Seasonal Worker Programme. Canberra: The Parliament of the Commonwealth of Australia, 2016.

Ka'ili, Tēvita. Marking Indigeneity: The Tongan Art of Sociospatial Relations. Arizona: The University of Arizona Press, 2017. doi.org/10.2307/j.ctt1t89kr9.

Kipnis, Andrew. 'Anthropology and the Theorisation of Citizenship'. The Asia Pacific Journal of Anthropology 5, no. 3 (2004): 257-78. doi.org/10.1080/ 1444221042000299592.

Korzeniwicz, Roberto Patricio and Timothy Patrick Moran. Unveiling Inequality: A World-Historical Perspective. New York: Russell Sage Foundation, 2009.

Maclellan, Nic and Peter Mares. 'Remittances and Labour Mobility in the Pacific: A Working Paper on Seasonal Work Programs in Australia for Pacific Islanders'. Melbourne: Institute for Social Research, Swinburne University of Technology, 2006.

MacDermott, Therese and Brian Opeskin. 'Regulating Pacific Seasonal Labour in Australia'. Pacific Affairs 83, no. 2 (2010): 283-305. doi.org/10.5509/ 2010832283.

Mares, Peter and Nic Maclellan. 'Pacific Seasonal Workers for Australian Horticulture: A Neat Fit?'. Asian and Pacific Migration Journal 16, no. 2 (2007): 271-88. doi.org/10.1177/011719680701600207.

Mence, Victoria, Simone Gangell and Ryan Tebb. A History of the Department of Immigration: Managing Migration to Australia. Belconnen: Department of Immigration and Border Protection, 2017.

Missingham, Bruce, Jacqui Dibden and Chris Cocklin. 'A Multicultural Countryside? Ethnic Minorities in Rural Australia'. Rural Society 16, no. 2 (2006): 131-50. doi.org/10.5172/rsj.351.16.2.131.

Moala-Tupou, Lupe. 'The Social Impacts of Seasonal Migration on Left behind Children: An Exploratory Study from Lifuka, Tonga'. MA thesis, University of Waikato, 2016.

Nishitani, Makiko and Helen Lee. 'Invisible Islanders? Precarious Work and Pacific Settlers in Rural Australia'. Pacific Studies 40, no. 3 (2017): 430-49. 
Quijano, Anibal. 'Coloniality of Power, Ethnocentrism, and Latin America'. Nepantla 1, no. 3 (2000): 533-80.

Rockell, Dennis. 'Pacific Island Labour Programmes in New Zealand: An Aid to Pacific Island Development? A Critical Lens on the Recognised Seasonal Employer Policy'. PhD thesis, Massey University, 2015.

Segrave, Marie. Exploited and Illegal: Unlawful Migrant Workers in Australia. Melbourne: The Border Crossing Observatory and the School of Social Sciences, Monash University, 2017.

Shachar, Ayelet. 'The Birthright Lottery: Response to Interlocutors'. Issues in Legal Scholarships 9, no. 1, Article 13 (2011): 1-25. doi.org/10.2202/15398323.1133.

Tazreiter, Claudia. Asylum Seekers and the State: Approaches to Protection in a Security-Conscious World. London: Ashgate, 2004.

Vas Dev, Sanjugta. 'Accounting for State Approaches to Asylum Seekers in Australia and Malaysia: The Significance of "National" Identity and "Exclusive" Citizenship in the Struggle against "Irregular" Mobility'. Identities: Global Studies in Culture and Power 16, no. 1 (2009): 33-60. doi.org/10.1080/ 10702890802605679.

\section{Newspapers}

The Age

The Christian Science Monitor

Fiji Sun

The Sydney Morning Herald 
This text is taken from Labour Lines and Colonial Power: Indigenous and Pacific Islander Labour Mobility in Australia, edited by Victoria Stead and Jon Altman, published 2019 by ANU Press, The Australian National University, Canberra, Australia.

doi.org/10.22459/LLCP.2019.07 